\title{
THE IMPLEMENTATION OF COOPERATIVE LEARNING OF TWO STAY TWO STRAY TYPE THROUGH STUDENTS' READING
}

\author{
${ }^{\# 1}$ Vevy Liansari, ${ }^{* 2}$ Ermawati Zulikhatin Nuroh, ${ }^{* 3}$ Evie Destiana \\ ${ }^{\# 1}$ English lecturer, Faculty of Psychology and Education Science, \\ Universitas Muhammadiyah Sidoarjo, Indonesia \\ ${ }^{* 2}$ English lecturer, Faculty of Psychology and Education Science, \\ Universitas Muhammadiyah Sidoarjo, Indonesia \\ ${ }^{* 3}$ Art lecturer, Faculty of Psychology and Education Science, \\ Universitas Muhammadiyah Sidoarjo, Indonesia
}

Corresponding Author Email: vevyliansari@umsida.ac.id

\section{A B S T R A C T S}

This study aims to determine the effect of the cooperative learning model type Two Stay Two Stray on the reading skills of third-grade students at SD Zainuddin, Waru, Sidoarjo. This study was conducted by using a quantitative approach of Pre-Experimental Design research with a OneGroup Post-test-Pre-test design. In this design, there is one group, namely the Experiment class. The results of this study indicated that there is an effect of the cooperative learning model type Two Stay Two Stray on the reading skills of third-grade students at SD Zainuddin, Waru, Sidoarjo. It is evident that the results of the data calculations that have been carried out obtained a significant value of .000 or $(.000<$ 0.05 ), or obtained $\mathrm{t}$-count $=43.071$ which was then compared with $\mathrm{t}$ table $=1.745$, with a significant level of $5 \%$ it is known that $\mathrm{t}$-count is greater 43,071 of t-table $=1,745$ ( $\mathrm{t}$-count $>\mathrm{t}$-table ). Thus, there is an effect of the cooperative learning model type Two Stay Two Stray on the reading skills of third-grade students at SD Zainuddin, Waru, Sidoarjo. This is evident from the results of the calculation of the researcher's hypothesis test with the one-sample t-test. These results are known that $\mathrm{Ha}$ is accepted and $\mathrm{H} 0$ is rejected with a significant value obtained .000 or $(.000<0.05)$.

\author{
A R T I C L E I N F O \\ Article History: \\ Received: March, 2021
}

Revised: May, 2021

Published: June, 2021

\section{Keywords:}

Cooperative Learning,

Two Stay Two Stray,

Reading,

How to cite: Liansari, V., Nuroh, E., \& Destiana, E. (2021). The Implementation of Cooperative Learning of Two Stay Two Stray Type through Students' Reading. Jo-ELT (Journal of English Language Teaching) Fakultas Pendidikan Bahasa \& Seni Prodi Pendidikan Bahasa Inggris IKIP, 8(1), 94-98. doi:https://doi.org/10.33394/jo-elt.v8i1.3573

\section{INTRODUCTION}

Reading skills are language skills that must be mastered by students before mastering other skills. Saddhono (2014: 6) explained that these skills are used by someone to communicate through spoken language or pronunciation to obtain messages or information about life. Therefore, students must be taught these language skills simultaneously so that students can master and develop other skills in order to support the achievement of success in learning a language. In addition, Nurgiyantoro (2014: 353) said that various efforts have been made by the teacher so that students in reading activities can understand learning and focus, 
as we know students prefer to study together with groups and ask friends rather than teachers. For this, the teacher will use a learning model.

Along with the times in the world of education, of course, innovative and creative learning models or methods will be created. One of the learning models used in this problem is the Two Stay Two Stray Model. It is supported by Lie (2002: 222) the Two Stay Two Stray learning model, which prioritizes providing information and seeking information. This learning model provides an opportunity for all groups to provide results and information to other groups. Two students who "live" in the group will provide results and information to other students as "guests".

In Two Stay Two Stray Model as a group learning system with the aim that students can work together, be responsible, help each other solve problems, and encourage each other to achieve. The group members who visit will be tasked with recording the results of discussions with other groups they visit and giving the results of the discussions to their homegroup. The Two Stay Two Stray model is This model can be used in all subjects and for all age levels of students. Huda (2013: 207) concludes that this model also trains students to socialize well learning model in which students will solve problems with their groups. The teacher will divide the group, each group will discuss the problem. After discussing two of the group members will visit another group or "the host" to seek information and note what they can relate to the problems given by the teacher. Two people who live in the group will present the results of their discussion and exchange information with the two visiting students from other groups. Moreover, Aqib (2013: 35) added that it can help students who are less able to socialize, with this model students will begin to get used to learning with groups. This model can be used in all subjects and levels in helping students to work together between groups, by providing motivation and solving problems by finding solutions together with satisfactory results.

\section{RESEARCH METHOD}

In this study, the researcher used a quantitative study with an experimental approach method, namely a study used to seek treatment of others to find out the controlled situation (Sugiyono, 2017). It was to test the cooperative learning model type Two Stay Two Stray on reading skills material in third-grade of SD Zainuddin, Waru, Sidoarjo. Thus, this study uses Pre-Experimental Designs (Non-designs) using One-Group Pre-test Post-test Design).

\section{Research Design}

This study was to test the cooperative learning model type Two Stay Two Stray on reading skills material for elementary students. This study uses Pre-Experimental Design (Non-designs) by using One-Group Pre-test Post-test Design.

\section{Population and Sample}

The population is a generalization area consisting of objects or subjects that have certain qualities and characteristics that are determined by the researcher to study and then draw conclusions. So, the population in this study was SD Zainudddin, Waru, Sidoarjo.

The sampling technique is a sampling technique. The research sample is part of the number of characteristics possessed by the population (Sugiyono, 2015). The sampling technique used in this study is Non-Probability Sampling, which is a sampling technique that does not provide equal opportunities or opportunities for each element or member of the population to be selected as a sample. The sampling technique used is saturated sampling, 
this sampling technique when all members of the population are used as samples. So, the sample in this research were students in third-grade elementary school students.

\section{Instruments}

A research instrument is a tool used to measure specifically the phenomena that occur, both natural and social (Riduwan, 2013). The instrument used in this study was a test instrument. The test question sheet is the main instrument in this study. It is used to measure students' reading skills using the Two Stay Two Stray type of cooperative learning model. The following is the content of the test in the form of descriptive questions that refer to indicators of reading skills and are adjusted to competencies and subject matter in accordance with the applicable curriculum. To make it easier for researchers to conduct research, the researchers arranged questions using a grid of question indicators and guidelines or scoring in providing an assessment of student answers. To compare the results of the tests before (pretest) and after (post-test) that have been given treatment by providing a cooperative learning model type Two Stay Two Stray. The researcher provided a pre-test and post-test using the instruments to be compiled.

\section{Data Analysis}

Data analysis in this research was to use a one-sample t-test to determine the effect of the cooperative learning model type Two Stay Two Stray on students' reading skills. However, before testing the one-sample t-test, the researcher first carried out a normality test. The normality test was used to determine the results of the pre-test and post-test data values carried out by researchers to determine whether they were normally distributed or not.

The researcher used a normality test to conduct the data (Riduwan, 2015). It has been concluded that the results of the normality test of the data above indicate that the value of the One-sample Kolmogorov-Smirnov test statistic is 0.111 and Asymp. sig is not significant at 0.200 or $(0.200>0.05)$, so it can be concluded that the data is normally distributed. After doing the normality test and it is known that the concept of understanding the concept of data is normally distributed. Researchers conducted a hypothesis test that aims to answer the formulation of the problem, namely is there any effect of the type Two Stay Two Stray cooperative learning model on the reading skills of third-grade students at SD Zainuddin, Waru, Sidoarjo. This study uses a significant level of $5 \%$.

\section{RESEARCH FINDINGS AND DISCUSSION Research Findings}

Based on the results of the research above, the results of testing the validity of the test show that in the column $r$ table, all test items show the correlation value of the test question items more than ( 0.444 or $\mathrm{N}=20), 12$ items are valid while 3 test questions invalid. So it can be said that of the 15 test questions from (r-count $>$ r-table) it is said to be valid, otherwise, it is not valid if (r-count $<\mathrm{r}$-table). For empirical validity, it is known that the results are valid in the high category so that all test questions can be used in real research.

Then, based on the results of the reliability test conducted using the SPSS version 24 program, the results of Cronbach Alpha are in the 0.60-0.80 category with the results of 0.696 being said to be in the high category, where each item is said to be reliable or trustworthy as a data collection tool in research. The results of the pre-test scores carried out by research on third-grade students of SD Zainuddin, Waru, Sidoarjo obtained the highest score of 78 and the lowest score of 65 to obtain an average score of 71.33 . However, after being treated using 
a two-stay two-stray cooperative learning model, this study experienced an increase in the score, which can be seen from the results of the post-test students with the highest score of 93 and the lowest score of 77 so that the average value of 83.61 can be seen. The results of the pre-test with a mean of 71.33 and the post-test results with a mean of 83.61 obtained an increase of 12.28 .

The results of the data normality test using the help of SPSS version 24 obtained a Kolmogorov-Smirnov significant value of 0.200 , indicating that the data is distributed normally because it has a significant value of more than 0.05 . Then for hypothesis testing using a one-sample t-test, it shows that there is a significant effect of the Two Stay Two Stray types of cooperative learning model on the reading skills of third-grade students at SD Zainuddin, Waru, Sidoarjo with a value of $0.000(0.000<0.05)$, or obtained from the result of $\mathrm{t}$-count is 43.071 and $\mathrm{t}$-table is 1.745 . Because $\mathrm{t}$-table < $\mathrm{t}$-count $(1.745<43.071)$, it can be concluded that $\mathrm{HO}$ is rejected and $\mathrm{Ha}$ is accepted.

\section{Discussion}

Based on the results of the study, Two Stay Two Stray type of cooperative learning model invites students to study with other students in a state of cooperation and have many opportunities to exchange information and improve understanding of the material in the learning. Students are divided into tasks to share the results of their discussions with other groups, there are students who are tasked with receiving the results of discussions from other groups. In each group, students have their own duties and students have their respective responsibilities in carrying out their duties. Thus, that the atmosphere in learning takes place with mutual trust, open interaction, and provides opportunities for each student to express their opinions both from their group and to other groups.

In addition, learning using the Two Stay Two Stray type of cooperative learning model takes a long time and researchers tend to have difficulties in classroom management. Therefore, to do learning using the cooperative learning model type Two Stay Two Stray requires long preparation. So that further researchers must prepare carefully both class management and materials, personnel, and funds. The last one is the learning tools in further research, which is to pay more attention to the syntax of the learning model in the lesson plans and to study all the learning tools first so that their mastery is more mature.

\section{CONCLUSION}

Based on research processes and data analysis, it concluded that the Alternative Hypothesis (Ha) which states that the learning model of Two Stay Two Stray through reading in third-grade elementary school students, is rejected. While the Null Hypothesis (Ho) states that the learning model of Two Stay Two Stray through reading in third-grade elementary school students, is accepted. The results showed that there was no effect of giving a learning model of Two Stay Two Stray through reading in third-grade elementary school students, but the data showed that there was an increase in scores in the experimental group although not significant. In addition, it was found that there were significant differences between the control group and the experimental group, so it was necessary to conduct further research on this topic.

\section{REFERENCES}

Aqib, Z. (2013). Model-Model, Media, dan Strategi Pembelajaran Kontekstual (Inovatif). Yogyakarta: Yrama Widya. 
Huda, M. (2013). Model-Model Pengajaran dan Pembelajaran. Yogyakarta: Pustaka Pelajar.

Lie, A. (2002). Cooperative Learning: Mempraktikkan Cooperative Learning di RuangRuang Kelas. Yogyakarta: PT Grasindo.

Nurgiyantoro, B. (2014). Penilaian Pembelajaran Berbahasa Berbasis Kompetensi. Yogyakarta : BPFE-YOGYAKARTA.

Riduwan. (2013). Dasar-Dasar Statistika. Bandung: Alfabeta.

Riduwan. (2015). Belajar Mudah Penelitian untuk Guru-Karyawan dan Peneliti Pemula. Bandung : Alfabeta.

Saddhono, K,. \& dkk. (2014). Pembelajaran Keterampilan Berbahasa Indonesia. Yogyakarta: Graha Ilmu.

Sugiyono. (2015). Statistika untuk Penelitian. Bandung : Alfabeta.

Sugiyono. (2017). Metode Penelitian Pendidikan Pendekatan Kuantitatif, Kualitatif, dan $R \& D$. Bandung: Alfabeta. 